\title{
Clinical heterogeneity and novel pathogenic variants of Chinese patients with neuroacanthocytosis
}

\author{
Hao Yu \\ Zhejiang University School of Medicine Second Affiliated Hospital \\ Liang Zhang \\ Zhejiang University School of Medicine Second Affiliated Hospital \\ Xiao-Yan Li \\ Zhejiang University School of Medicine Second Affiliated Hospital \\ Zhi-Ying Wu ( $\nabla$ zhiyingwu@zju.edu.cn ) \\ Zhejiang University School of Medicine Second Affiliated Hospital https://orcid.org/0000-0003-2106-572X
}

\section{Research}

Keywords: Neuroacanthocytosis, McLeod syndrome, Chorea-acanthocytosis, XK, VPS13A

Posted Date: April 27th, 2020

DOI: https://doi.org/10.21203/rs.3.rs-23935/v1

License: () (1) This work is licensed under a Creative Commons Attribution 4.0 International License. Read Full License 


\section{Abstract \\ Background}

Neuroacanthocytosis (NA) syndromes are a group of exceedingly rare diseases, including McLeod syndrome (MLS) and chorea-acanthocytosis (ChAc). The characteristic phenotypes comprise a variety of movement disorders, including chorea, dystonia, and parkinsonism. We aimed to investigate the clinical heterogeneity and novel pathogenic variants of Chinese patients with neuroacanthocytosis.

\section{Results}

Three novel $X K$ variants (c.942G > A, c.970A > T, c.422_423del) were identified in three index MLS patients and three novel VPS13A variants (c.3817C > T, c.9219C > A , c.3467T > A) in two index ChAc patients. In addition, we summarized the genotypes and phenotypes of reported MLA patients and ChAc patients in the Chinese population.

\section{Conclusion}

Our study expands the genetic spectrum of $X K$ and VPS13A and helps the clinical diagnosis of neuroacanthocytosis.

\section{Introduction}

Neuroacanthocytosis (NA) is a group of syndromes, including McLeod syndrome (MLS), chorea-acanthocytosis (ChAc), Huntington's disease-like 2 (HDL2), and pantothenate kinase-associated neurodegeneration (PKAN). The acanthocytosis is a frequent finding in MLS and ChAc, but only occurs in approximately $10 \%$ of HDL2 and PKAN patients [1]. The "core" neuropathologic finding in NA syndromes is the degeneration affecting the basal ganglia, thus their clinical presentations can be remarkably similar [2]. The characteristic phenotypes comprise psychiatric and cognitive symptoms, and a variety of movement disorders including chorea, dystonia, and parkinsonism. The age of onset, inheritance pattern and ethnic background provide diagnostic clues in each condition, but clinical diagnosis remains challenging. Genetic diagnosis provides a definitive diagnosis and is important for genetic counseling.

In the two core NA syndromes, MLS is inherited in an X-linked way with pathogenic variants of $X K$ gene, while ChAc is an autosomal recessive disorder caused by pathogenic variants in VPS13A. It is estimated that there are likely a few hundred of MLS patients and around one thousand ChAc patients in the world [2]. Although more than 50 NA patients have so far been reported in China [3-12], most of which were not confirmed by specific molecular tests [3]. The distribution of pathogenic variants within XK and VPS13A has not been conclusively determined in China.

Targeted next-generation sequencing (NGS) has been successfully utilized to diagnose neurological diseases which may be difficult to differentiate from clinical symptoms. In this study, we collected 14 unrelated Chinese patients who exhibited involuntary chorea and had been ruled out the Huntington's disease (HD) by the HTT gene testing. We performed targeted NGS in these patients and 5 index patients were diagnosed with MLS or ChAc by Sanger sequencing verification. Three novel $X K$ variants and three novel VPS13A variants were identified

\section{Methods Subjects}

Fourteen unrelated patients who presented suspected chorea with negative HTT genetic testing and their familial members were recruited between June 2015 and March 2019. The neurological examinations and clinical evaluations were performed by at least two senior neurologists. Routine blood tests and radiological examinations were performed. The study was approved by the Ethics Committee of Second Affiliated Hospital, Zhejiang University School of Medicine. Written informed consent was obtained from each participant.

\section{Acanthocyte examination}

Blood was collected into the tube containing ethylene-diamine-tetracetic acid (EDTA) and examined by scanning electron microscopy (SEM). Red cells were fixed in a $1 \%$ solution of glutaraldehyde and stored at $4{ }^{\circ} \mathrm{C}$ until the time of examination. The red cells were absorbed onto tissue paper and goldcoated with an Emscope Sputter Coater. They were then examined in a Nova nano 450 electron microscope operating at $5 \mathrm{kV}$. The acanthocyte rate was counted as the method described previously[13].

\section{Genetic analysis}

Genomic DNA was extracted from peripheral EDTA-treated blood by Blood Genomic Extraction Kit (Qiagen, Hilden, Germany). A customized panel was designed to cover 54 genes for chorea and dystonia, including VPS13A, XK, PRNP, 10 genes of neurodegeneration with brain iron accumulation (NBIA), 4 genes of familial basal ganglia calcification, and other 37 genes of hereditary dystonia (Supplemental Table 1). A detailed protocol of NGS was reported in our previous study [14]. Sanger sequencing was performed on an ABI 3500xI Dx Genetic Analyzer (Applied Biosystems, Foster City, USA) as our 
previous report to verify the filtered potential variants [15]. Co-segregation analysis was carried out in families with genetic variants. SIFT and PolyPhen-

2 were used to predict the pathogenicity of the identified variants.

\section{Results}

\section{Identification of novel XK and VPS13A variants}

After targeted NGS and Sanger sequencing, three novel hemizygous variants within $X K$ gene were found in three index patients (Fig. 1A-C). Among these three variants, two are nonsense (c.942G $>A$ and c.970A $>T$ ) and one is frameshift (c.422_423del). They are all absent in 1000G, gnomAD and our NGS database containing 500 Chinese matched controls. According to American College of Medical Genetics and Genomics (ACMG) standards [16], c.942G $>\mathrm{A}$ is classified as pathogenic and the other two variants c.970A $>\mathrm{T}$ and c.422_423del are classified as likely pathogenic (Table 1).

Table 1

The identified variants of five patients with neuroacanthocytosis syndromes

\begin{tabular}{|c|c|c|c|c|c|c|c|c|c|c|c|}
\hline Gene & $\begin{array}{l}\text { Case } \\
\text { no. }\end{array}$ & Refseq NM & $\begin{array}{l}\text { Nucleotide } \\
\text { change }\end{array}$ & $\begin{array}{l}\text { Amino acid } \\
\text { change }\end{array}$ & Exon & $\begin{array}{l}\text { Variant } \\
\text { type }\end{array}$ & $\begin{array}{l}1000 \mathrm{G} \\
\text { (All) }\end{array}$ & $\begin{array}{l}\text { gnomAD } \\
\text { (All) }\end{array}$ & SIFT & Polyphen2 & $\begin{array}{l}\text { ACMG } \\
\text { classification } \\
\text { (pathogenic } \\
\text { criterion) }\end{array}$ \\
\hline \multirow[t]{2}{*}{$X K$} & 1 & NM_021083.3 & c. $422 \_423 \mathrm{del}$ & p.V141Dfs*57 & 2 & Hemi & 0 & 0 & NA & NA & $\begin{array}{l}\text { Likely } \\
\text { Pathogenic } \\
\text { (I) }\end{array}$ \\
\hline & & & & & & & & & & & $\begin{array}{l}\text { (PVS1 + } \\
\text { PM2) }\end{array}$ \\
\hline \multirow[t]{2}{*}{$X K$} & 2 & NM_021083.3 & c. $942 G>A$ & p.W314* & 3 & Hemi & 0 & 0 & NA & NA & $\begin{array}{l}\text { Pathogenic } \\
\text { (la) }\end{array}$ \\
\hline & & & & & & & & & & & $\begin{array}{l}\text { (PVS1 + PS1 } \\
\text { + PM2) }\end{array}$ \\
\hline \multirow[t]{2}{*}{$X K$} & 3 & NM_021083.3 & c. $970 \mathrm{~A}>\mathrm{T}$ & p.R324* & 3 & Hemi & 0 & 2 & NA & NA & $\begin{array}{l}\text { Likely } \\
\text { Pathogenic } \\
\text { (I) }\end{array}$ \\
\hline & & & & & & & & & & & $\begin{array}{l}\text { (PVS1 + } \\
\text { PM2) }\end{array}$ \\
\hline \multirow[t]{2}{*}{ VPS13A } & 4 & NM_033305.2 & c. $3817 \mathrm{C}>\mathrm{T}$ & p.R1273* & 34 & Hom & 0 & 1 & NA & NA & $\begin{array}{l}\text { Likely } \\
\text { Pathogenic } \\
\text { (I) }\end{array}$ \\
\hline & & & & & & & & & & & $\begin{array}{l}\text { (PVS1 + } \\
\text { PM2) }\end{array}$ \\
\hline VPS13A & 5 & NM_033305.2 & c. $3467 \mathrm{~T}>\mathrm{A}$ & p. $11156 \mathrm{~N}$ & 32 & Het & 0 & 0 & D & Prob D & $\begin{array}{l}\text { Likely } \\
\text { Pathogenic } \\
\text { (V) (PM2+ } \\
\text { PM3 + PP3 + } \\
\text { PP4) }\end{array}$ \\
\hline \multirow[t]{2}{*}{ VPS13A } & 5 & NM_033305.2 & c. $9219 \mathrm{C}>\mathrm{A}$ & p.Y3073* & 69 & Het & 0 & 0 & NA & NA & $\begin{array}{l}\text { Pathogenic } \\
\text { (la) }\end{array}$ \\
\hline & & & & & & & & & & & $\begin{array}{l}\text { (PVS1 + PS1 } \\
+ \text { + PM2 + } \\
\text { PP4) }\end{array}$ \\
\hline $\begin{array}{l}\text { Hemi: hen } \\
\text { 2/SIFT: S } \\
\text { ACMG: Ar } \\
\text { (PM1-6), }\end{array}$ & $\begin{array}{l}\text { zygou } \\
\text { tware } \\
\text { arican }\end{array}$ & $\begin{array}{l}\text { Hom: homozyg } \\
\text { ediction progra } \\
\text { llege of Medice } \\
\text { ng (PP1-5). }\end{array}$ & $\begin{array}{l}\text { Is; Het: heteroz } \\
\text { s used for seq } \\
\text { Genetics and }\end{array}$ & $\begin{array}{l}\text { jous; } 1000 \mathrm{G}: 1 \\
\text { nce variant eff } \\
\text { nomics. Each }\end{array}$ & $\begin{array}{l}\text { Geno } \\
\text { explar } \\
\text { oogeni }\end{array}$ & $\begin{array}{l}\text { es Projec } \\
\text { tion; D: d } \\
\text { rriterion }\end{array}$ & $\begin{array}{l}\text { gnom } \\
\text { naging } \\
\text { Neight }\end{array}$ & $\begin{array}{l}\text { Genome } \\
\text { ob D, pro } \\
\text { as very st }\end{array}$ & $\begin{array}{l}\text { reg } \\
\text { ly d } \\
\text { a (P) }\end{array}$ & $\begin{array}{l}\text { natabase } \\
\text { aging; NA: n } \\
\text { 1), strong (P }\end{array}$ & $\begin{array}{l}\text { olyPhen } \\
\text { available; } \\
\text {-4), moderate }\end{array}$ \\
\hline
\end{tabular}

In addition, three novel variants within VPS13A gene were detected in another two index patients, one of whom harbored a homozygous variant (c.3817C > T) and the other harbored compound heterozygous variants (c.3467T >A and c.9219C >A) (Fig. 1D-E). Among these variants, two are nonsense (c.3817C > T and c.9219C >A) and one is missense (c.3467T >A). The three variants are at extremely low frequency in gnomAD ( $<=2)$ and absent in 1000 and our NGS database. The missense variant c.3467T > A was predicted to be deleterious by SIFT and PolyPhen-2. According to ACMG standards, c.9219C > A is classified as pathogenic, while c.3817C > T and c.3467T > A are classified as likely pathogenic (Table 1).

\section{Clinical features of five genetically diagnosed patients}

The detailed clinical features of five NA patients are summarized in Table 2. Three MLS index patients were all males with no family history of NA (Fig. 1A-C). Two ChAc index patients were females, one of which was from consanguineous marriage (Fig. 1D) and the other had a positive family history (Fig. 1E). All five patients had mild to moderate elevated creatine kinase (CK). Four patients had generalized chorea-like symptoms, and the brain 
magnetic resonance imaging (MRI) of them revealed atrophy of either caudate or putamina (Fig. 2A-D). One MLS case (Case 2) showed relative mild involuntary movements mainly on his fingers and marked elevated CK, which made it confused with myopathy at first. Reflexes of five NA patients were all reduced. Two of them took electromyogram (EMG) and showed axonal neuropathy. Apart from one case undetected, the acanthocyte rate of peripheral blood in four patients was between 18-32\%, which was easily recognized in electron microscopy (Fig. 2E-F).

Table 2

Clinical features of five index patients with neuroacanthocytosis syndromes

\begin{tabular}{|c|c|c|c|c|c|}
\hline Variable & Case 1 & Case 2 & Case 3 & Case 4 & Case 5 \\
\hline Diagnosis & MLS & MLS & MLS & ChAc & ChAc \\
\hline Gender/Age & Male/47 & Male/41 & Male/57 & Female/35 & Female/61 \\
\hline Age of onset & 26 & 37 & 53 & Early of $20 \mathrm{~s}$ & 50 \\
\hline Family history & - & - & - & - & + \\
\hline $\begin{array}{l}\text { Primary } \\
\text { symptoms }\end{array}$ & $\begin{array}{l}\text { Involuntary tongue and limb } \\
\text { movements }\end{array}$ & $\begin{array}{l}\text { Gait } \\
\text { disturbance }\end{array}$ & $\begin{array}{l}\text { Involuntary limb } \\
\text { movements }\end{array}$ & $\begin{array}{l}\text { Involuntary tongue and } \\
\text { limb movements }\end{array}$ & $\begin{array}{l}\text { Involuntary tongue and } \\
\text { limb movements }\end{array}$ \\
\hline Chorea & Generalized & Mild & Generalized & Generalized & Generalized \\
\hline Dysarthria & + & - & + & + & + \\
\hline $\begin{array}{l}\text { Orofacial } \\
\text { dyskinesias }\end{array}$ & + & - & + & + & + \\
\hline $\begin{array}{l}\text { Tongue and } \\
\text { lip biting }\end{array}$ & - & - & - & + & - \\
\hline $\begin{array}{l}\text { Parkinsonian } \\
\text { features }\end{array}$ & Bradykinesia & Bradykinesia & - & - & - \\
\hline Seizure & Generalized & - & - & Generalized & - \\
\hline $\begin{array}{l}\text { Psychiatric } \\
\text { symptoms }\end{array}$ & Depression & Anxiety & Depression & Depression & Anxiety \\
\hline EMG & Axonal neuropathy & $\begin{array}{l}\text { Axonal } \\
\text { neuropathy }\end{array}$ & NA & NA & NA \\
\hline CK (U/L) & 753 & 2244 & 345 & 332 & 252 \\
\hline $\begin{array}{l}\text { ALT/AST } \\
(U / L)\end{array}$ & $24 / 31$ & $90 / 85$ & $119 / 29$ & $14 / 18$ & $28 / 28$ \\
\hline $\begin{array}{l}\text { Acanthocyte } \\
\text { ratio }\end{array}$ & $18 \%$ & $22 \%$ & NA & $32 \%$ & $30 \%$ \\
\hline MRI & $\begin{array}{l}\text { atrophy of the heads of the } \\
\text { caudate nuclei }\end{array}$ & NA & $\begin{array}{l}\text { atrophy of putamina } \\
\text { and caudate }\end{array}$ & $\begin{array}{l}\text { atrophy of putamina and } \\
\text { caudate }\end{array}$ & $\begin{array}{l}\text { atrophy of putamina and } \\
\text { caudate }\end{array}$ \\
\hline
\end{tabular}

Case 1

(II-2 in Family 1, Fig. 1A) was a 47-year-old male with involuntary tongue and limb movements for over 20 years. At age 43, he noted progressive gait disturbance and tendency to fall. He went to the hospital and was diagnosed with "chorea". Then he was treated with risperidone and discontinued after several months. At age 47, he had a general tonic-clonic seizure and was treated with valproate. Neurological examinations showed dysarthria and $4 / 5$ weakness of left proximal lower limb.

Case 2

(II-4 in in Family 2, Fig. 1B) was a 41-year-old male with gait disturbance for 4 years. At age 37, he noted progressive gait disturbance and tendency to fall. Neurological examinations showed mild postural instability and slight gait unsteadiness. Mild involuntary movements of his fingers were noted.

\section{Case 3}

(II-1 in Family 3, Fig. 1C) was a 57-year-old male with involuntary limb movements for 4 years. At age 53, he noted episodic involuntary movements of lower limbs. The frequency and region developed progressively. At age 56, the involuntary movements affected the upper limbs and neck, and gait disturbance was significant with frequent falls. Neurological examinations showed general choreiform movements and gait unsteadiness.

Case 4 
(II-2 in Family 4, Fig. 1D) was a 35-year-old female with involuntary limb movements for over 10 years. Her parents had a consanguineous marriage. At early of $20 \mathrm{~s}$, she presented mild involuntary movements which did not affect daily life. The symptoms worsen gradually and she developed dysarthria, drooling, orofacial dyskinesias with tongue and lip biting in the following years. At age 35 , she had two generalized tonic-clonic seizures and was treated with levetiracetam. Neurological examinations showed general choreiform movements with dysarthria and orofacial dyskinesias.

Case 5

(II-2 in Family 5, Fig. 1E) was a 61-year-old female with involuntary limb movements for over 10 years. At age of about 50, she began to present with progressive general involuntary movements and then gradually developed dysarthria, orofacial dyskinesias and shoulder shrugging. She had a 50-yearold brother who presented with similar symptoms at age of $40 \mathrm{~s}$ and could not walk right now. Her neurological examinations showed general choreiform movements with dysarthria and orofacial dyskinesias.

\section{Discussion}

Neuroacanthocytosis syndromes are all exceedingly rare with an estimate prevalence of less than 1 to 5 per 1,000,000 for each disorder worldwide [2]. Currently, 43 pathogenic variants of XK gene have been included in the Human Gene Mutation Database (HGMD, v2019.4), including 13 missense/ nonsense variants, 6 splicing variants, 12 small deletion/ insertion/ indels and 12 gross deletions. In the Chinese population, there were 6 pathogenic variants of $X K$ gene have been reported (Table 3), two of which were included in HGMD. Combined with three novel variants in the current study, there are 9 pathogenic $X K$ variants including five nonsense variants, two small deletions and two gross deletions. ChAc are relatively more common than MLS. There are 126 pathogenic variants of VPS13A in HGMD, including 41 missense/ nonsense variants, 25 splicing variants, 48 small deletion/ insertion/ indels and 12 gross deletion/ insertion/ complex rearrangements. Combined with three novel variants in our study, there are 10 pathogenic VPS13A variants in the Chinese population (Table 1 and Table 3), including 7 missense/ nonsense variants, one splicing variant and two small insertion/ deletions. These 19 pathogenic variants were all from single families and we did not find any hotspot variant in the Chinese population.

Table 3

Reported Chinese patients with neuroacanthocytosis

\begin{tabular}{|c|c|c|c|c|c|c|c|c|c|}
\hline $\begin{array}{l}\text { Index } \\
\text { no. }\end{array}$ & Gene & $\begin{array}{l}\text { Nucleotide change (Amino } \\
\text { acid change) }\end{array}$ & Exon & $\begin{array}{l}\text { Variant } \\
\text { type }\end{array}$ & HGMD & AAO & Main clinical symptoms & $\begin{array}{l}\mathrm{CK} \\
(\mathrm{U} / \mathrm{L})\end{array}$ & Language \\
\hline 1 & $X K$ & c.856_860del (p.L286Yfs*16) & 3 & Hemi & DM & $\stackrel{40+}{Y}$ & $\begin{array}{l}\text { Wasting of limb muscles, chorea } \\
\text { of feet }\end{array}$ & 2148 & $\begin{array}{l}\text { English } \\
{[4]}\end{array}$ \\
\hline 2 & $X K$ & c. $154 \mathrm{C}>\mathrm{T}\left(\mathrm{p} . \mathrm{Q} 52^{*}\right)$ & 1 & Hemi & DM & $62 Y$ & $\begin{array}{l}\text { Myalgia, muscle fatigue, chorea } \\
\text { of toes }\end{array}$ & $\begin{array}{l}602- \\
3328\end{array}$ & $\begin{array}{l}\text { English } \\
\text { [5] }\end{array}$ \\
\hline 3 & $X K$ & $\begin{array}{l}\text { Gross deletion: entire gene + } \\
C Y B B+\text { ex.1-44 DMD }\end{array}$ & $1-3$ & Hemi & NA & $4 \mathrm{Y} 1 \mathrm{M}$ & $\begin{array}{l}\text { Chronic granulomatous disease, } \\
\text { unexpected discovery }\end{array}$ & 7149 & $\begin{array}{l}\text { Chinese } \\
\text { [6] }\end{array}$ \\
\hline 4 & $X K$ & $\begin{array}{l}\text { Gross deletion: entire gene + } \\
C Y B B+\text { ex.1-2 DMD }\end{array}$ & $1-3$ & Hemi & NA & $1 Y 9 M$ & $\begin{array}{l}\text { Chronic granulomatous disease, } \\
\text { unexpected discovery }\end{array}$ & 2837 & $\begin{array}{l}\text { Chinese } \\
\text { [6] }\end{array}$ \\
\hline 5 & $X K$ & c.89C $>A(p . S 30 *)$ & 1 & Hemi & NA & $10 \mathrm{M}$ & $\begin{array}{l}\text { Fever, seizure, unexpected } \\
\text { discovery }\end{array}$ & 14889 & $\begin{array}{l}\text { English } \\
{[7]}\end{array}$ \\
\hline 6 & $X K$ & c.1004G > A (p.W335*) & 3 & Hemi & NA & $\mathrm{Y}_{\mathrm{Y}}^{40+}$ & $\begin{array}{l}\text { Chorea of limbs, orolingual } \\
\text { dystonia }\end{array}$ & $\begin{array}{l}928- \\
1280\end{array}$ & $\begin{array}{l}\text { Chinese } \\
\text { [8] }\end{array}$ \\
\hline \multirow[t]{2}{*}{7} & \multirow[t]{2}{*}{ VPS13A } & $\begin{array}{l}\text { c.7280_7284del } \\
(\text { p.Y2427Sfs*6) }\end{array}$ & 52 & Het & DM & \multirow[t]{2}{*}{$30 Y$} & \multirow{2}{*}{$\begin{array}{l}\text { Chorea of limbs, orolingual } \\
\text { dystonia, tongue and lip biting, } \\
\text { seizure }\end{array}$} & \multirow[t]{2}{*}{1122} & \multirow{2}{*}{$\begin{array}{l}\text { English } \\
\text { [9] }\end{array}$} \\
\hline & & $c .8278 \mathrm{C}>\mathrm{T}(\mathrm{p} . \mathrm{Q} 2760 *)$ & 60 & Het & DM & & & & \\
\hline \multirow[t]{2}{*}{8} & \multirow[t]{2}{*}{ VPS13A } & c.8282C > G (p.S2761*) & 60 & Het & DM & \multirow[t]{2}{*}{$45 Y$} & \multirow{2}{*}{$\begin{array}{l}\text { Orolingual dystonia, tongue and } \\
\text { lip biting }\end{array}$} & \multirow[t]{2}{*}{137} & \multirow{2}{*}{$\begin{array}{l}\text { English } \\
\text { [9] }\end{array}$} \\
\hline & & c. $9276-1 \mathrm{G}>\mathrm{A}$ & 70 & Het & DM? & & & & \\
\hline 9 & VPS13A & c.486T > G (p.Y162*) & 6 & Hom & NA & $28 Y$ & $\begin{array}{l}\text { Chorea of limbs, orolingual } \\
\text { dystonia, tongue and lip biting, } \\
\text { seizure }\end{array}$ & 404 & $\begin{array}{l}\text { Chinese } \\
\text { [10] }\end{array}$ \\
\hline 10 & VPS13A & c.8823c > G (p.Y2941*) & 65 & Hom & DM & $26 Y$ & $\begin{array}{l}\text { Chorea of limbs, orolingual } \\
\text { dystonia, tongue and lip biting, } \\
\text { seizure }\end{array}$ & NA & $\begin{array}{l}\text { English } \\
\text { [11] }\end{array}$ \\
\hline 11 & VPS13A & c.80dup (p.S28Lfs*17) & 1 & Het & NA & $26 Y$ & $\begin{array}{l}\text { Chorea of limbs, orolingual } \\
\text { dystonia, tongue and lip biting }\end{array}$ & 453 & $\begin{array}{l}\text { English } \\
\text { [12] }\end{array}$ \\
\hline
\end{tabular}

MLS and ChAc share a number of similar features [17] and there is a striking phenotypic overlap in these two disorders, including age at onset, chorea, dysarthria, orofacial dyskinesia, seizures, psychiatric symptoms and brain MRI, but some clues may help to differentiate them. First, in genetics, MLS is inherited in an X-link way and ChAc in an autosomal recessive manner. Therefore, the family history and the gender can give important clues to help 
diagnosis. Besides, the gross deletion in $X K$ gene often involves adjacent genes such as $D M D, C Y B B, R P G R$ and $O T C$, and leads to concomitant disorders such as dystrophinopathy, chronic granulomatous disease, retinitis pigmentosa and ornithine transcarbamylase deficiency [18]. Although our patients did not have gross deletions, which have been reported in two Chinese patients with chronic granulomatous, whose $D M D$ genes were also involved [6]. It is important to screen MLS phenotype in males with chronic granulomatous disease for complication monitoring and management. In clinical manifestations, the orolingual dystonia is more frequently presented in ChAc. In our study and previous reports in the Chinese population, all ChAc patients had orolingual dystonia, but less than half MLS had the condition. In addition, the severity often disproportionate to other involuntary movements in ChAc. For example, self-mutilating tongue and lip biting, which present in $40 \%$ of Caucasians [19] and $85 \%$ (6/7) of reported Chinese ChAc patients, are very rare in MLS patients [17].

In the other hand, MLS patients seemed to have higher CK levels than ChAc in the Chinese population. About 78\% of MLS patients (7/9) had CK above $1000 \mathrm{U} / \mathrm{L}$, whereas only one of six ChAc patient reached this level. Moreover, MLS patients can have muscle complaints with mild involuntary movements, which often lead to a confusion with myopathy $[4,5]$. However, the EMG usually show axonal neuropathy, so sometimes these patients can be misdiagnosed with Kennedy's disease, which is also an X-link disorder manifests with proximal weakness, hyperCKemia, and axonal neuropathymimic EMG [20]. Therefore, it is important to pay attention to mild involuntary movement and differentiate MLS in males with both hyperCKemia and a neuropathic EMG. The acanthocyte rate in peripheral blood can usually fall 5-50\% in ChAc and 8-30\% in MLS [2], which is consistent with our results. However, the presence of acanthocytes may vary over time and can be absent in some cases [21-24], thus cannot be used to distinguish different NA syndromes.

\section{Conclusion}

In conclusion, we reported five Chinese NA families and identified three novel $X K$ variants (c.942G > A, c.970A>T, c.422_423del) in 3 index MLS patients and three novel VPS13A variants (c.3817C > T, c.9219C > A, c.3467T > A) in two index ChAc patients. In addition, we summarized the genotypes and phenotypes of reported MLA patients and ChAc patients in the Chinese population. Our study expands the genetic spectrum of $X K$ and $V P S 13 A$ and helps the clinical diagnosis of neuroacanthocytosis.

\section{Declarations}

\section{Ethics approval and consent to participate}

The study protocol was in accordance with the tenets of the Declaration of Helsinki and was approved by the Ethics Committee of Second Affiliated Hospital, Zhejiang University School of Medicine. Written informed consents were obtained from all the participants.

\section{Consent for publication}

Written informed consents for publication were obtained from all the participants.

\section{Availability of data and material}

The data that support the findings of this study are available from the corresponding author upon reasonable request.

\section{Competing interests}

The authors declare that they have no competing interests.

\section{Funding}

This work was supported by the research foundation for distinguished scholar of Zhejiang University to Zhi-Ying Wu (188020-1938 10101/089).

\section{Authors' contributions}

Hao Yu and Liang Zhang: data acquisition, analysis and interpretation, and manuscript preparation; Xiao-Yan Li: data acquisition, analysis and interpretation; Zhi-Ying Wu: study design and conception, data acquisition, analysis and interpretation, critical revision of the manuscript.

\section{Acknowledgements}

We would like to thank all participants for their willingness to participate in this study. 


\section{References}

1. Danek A, Walker RH. Neuroacanthocytosis. Curr Opin Neurol. 2005;18(4):386-92.

2. Jung HH, Danek A, Walker RH. Neuroacanthocytosis syndromes. Orphanet J Rare Dis. 2011;6:68.

3. Liu J, Bader B, Danek A. Neuroacanthocytosis in china: a review of published reports. Tremor Other Hyperkinet Mov (N Y). 2014;4:248.

4. Man BL, Yuen YP, Fu YP. The first report of a Chinese family with McLeod syndrome. BMJ Case Rep. 2014;2014.

5. Chen PY, Lai SC, Yang CC, et al. A novel XK gene mutation in a Taiwanese family with McLeod syndrome. J Neurol Sci. 2014;340(1-2):221-4.

6. He J, Guo Y, Feng X, et al. Chronic granulomatous disease and Mcleod syndrome caused by continuous X chromosome deletion: a report of two cases and literature review. J Clin Pediatr. 2016;34(8):614-7.

7. Tian PC, Wang Y, Chen Z, et al. The first case report of McLeod syndrome in an infant with a novel mutation (c.89C > A, p. Ser30X) in XK. Clin Neurol Neurosurg. 2019;184:105421.

8. Xu L, Hua P, Liu W, et al. A McLeod syndrome family and new novel XK gene mutation. Chin J Neurol. 2019;52(1):14-8.

9. Shen Y, Liu X, Long X, et al. Novel VPS13A Gene Mutations Identified in Patients Diagnosed with Chorea-acanthocytosis (ChAc): Case Presentation and Literature Review. Front Aging Neurosci. 2017;9:95.

10. Jin D, Sun H, Sun X, et al. Analysis of clinical phenotype and gene mutation in chorea-acanthocytosis with epilepsy as the initial onset: one case report. Chin J Contemp Neurol Neurosurg. 2018;18(5):349-54.

11. Yi F, Li W, Xie N, et al. Chorea-Acanthocytosis in a Chinese Family With a Pseudo-Dominant Inheritance Mode. Front Neurol. $2018 ; 9: 594$.

12. Xiang Y, Li S, Liu X, et al. Neuroacanthocytosis: a case report of chorea-acanthocytosis. J Integr Neurosci. 2019;18(2):197-201.

13. Hardie RJ, Pullon HW, Harding AE, et al. Neuroacanthocytosis. A clinical, haematological and pathological study of 19 cases. Brain. 1991;114(Pt 1A):13-49.

14. Liu ZJ, Lin HX, Liu GL, et al. The investigation of genetic and clinical features in Chinese patients with juvenile amyotrophic lateral sclerosis. Clin Genet. 2017;92(3):267-73.

15. Dong Y, Ni W, Chen WJ, et al. Spectrum and Classification of ATP7B Variants in a Large Cohort of Chinese Patients with Wilson's Disease Guides Genetic Diagnosis. Theranostics. 2016;6(5):638-49.

16. Richards S, Aziz N, Bale S, et al. Standards and guidelines for the interpretation of sequence variants: a joint consensus recommendation of the American College of Medical Genetics and Genomics and the Association for Molecular Pathology. Genet Med. 2015;17(5):405-24.

17. Walker RH. Management of Neuroacanthocytosis Syndromes. Tremor Other Hyperkinet Mov (N Y). 2015;5:346.

18. Peng J, Redman CM, Wu X, et al. Insights into extensive deletions around the XK locus associated with McLeod phenotype and characterization of two novel cases. Gene. 2007;392(1-2):142-50.

19. Danek A, Jung HH, Melone MA, et al. Neuroacanthocytosis: new developments in a neglected group of dementing disorders. J Neurol Sci. 2005;229-230:171-86.

20. Ni W, Chen S, Qiao K, Wang N, Wu ZY. Genotype-phenotype correlation in Chinese patients with spinal and bulbar muscular atrophy. PLoS One. 2015;10(3):e0122279.

21. Walker RH. Untangling the Thorns: Advances in the Neuroacanthocytosis Syndromes. J Mov Disord. 2015;8(2):41-54.

22. Danek A, Rubio JP, Rampoldi L, et al. McLeod neuroacanthocytosis: genotype and phenotype. Ann Neurol. 2001;50(6):755-64.

23. Bayreuther C, Borg M, Ferrero-Vacher C, Chaussenot A, Lebrun C. [Chorea-acanthocytosis without acanthocytes]. Rev Neurol (Paris). 2010;166(1):100-3.

24. Sorrentino G, De Renzo A, Miniello S, Nori O, Bonavita V. Late appearance of acanthocytes during the course of chorea-acanthocytosis. J Neurol Sci. 1999;163(2):175-8.

\section{Figures}



A Family 1
B Family 2
C Family 3
II
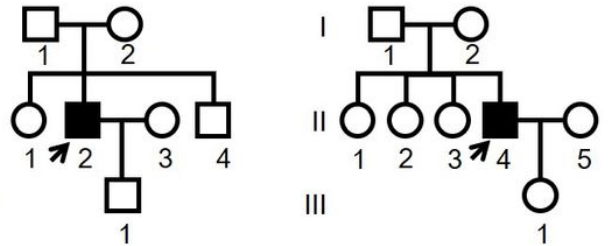
।
$\square$
II

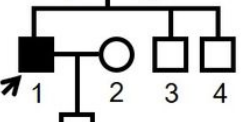
III
1
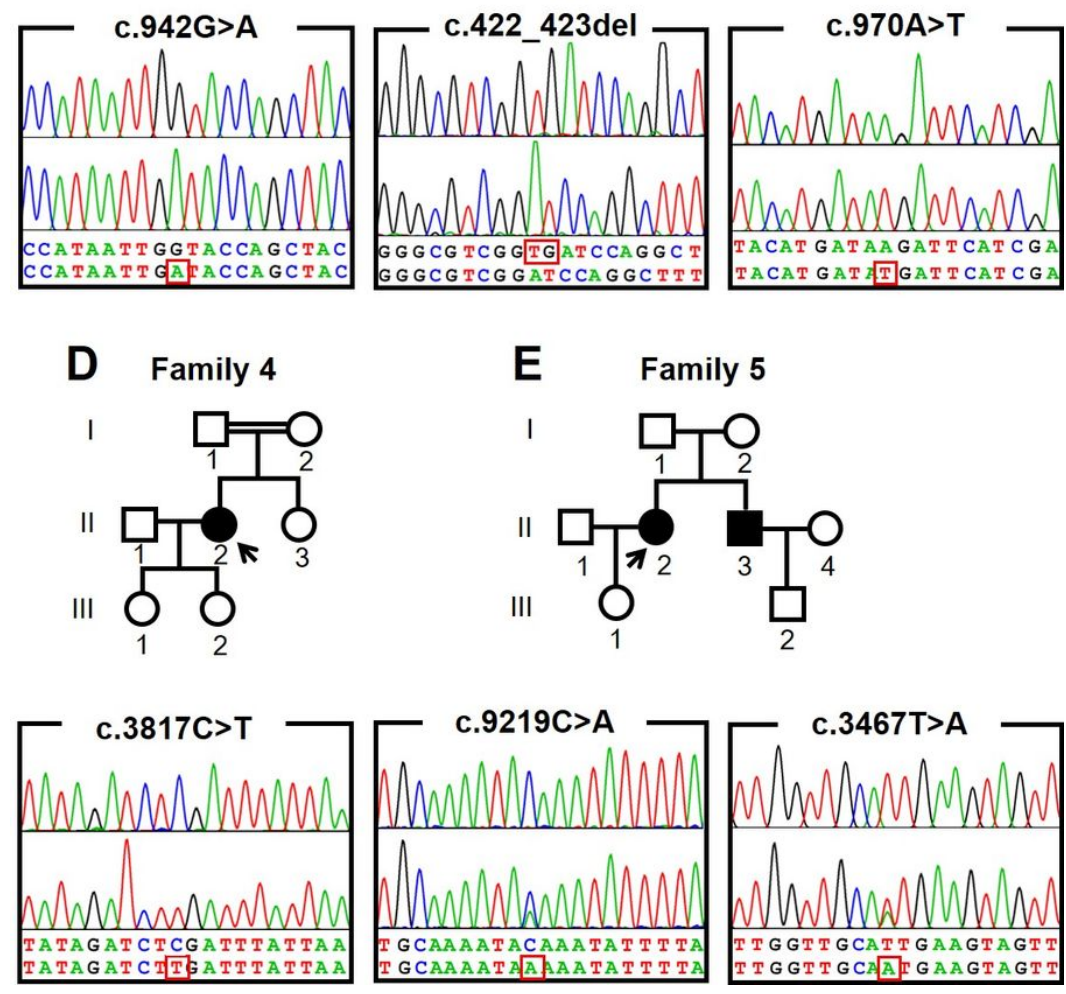

Figure 1

Pedigree chart of index families and chromatogram of novel variants detected in each family. Squares indicate males; circles indicate females; the black symbols indicate affected individuals; arrows indicate the probands. The upper panel in chromatogram depicts the reference sequence. The lower panel represents heterozygous mutated sequence. 

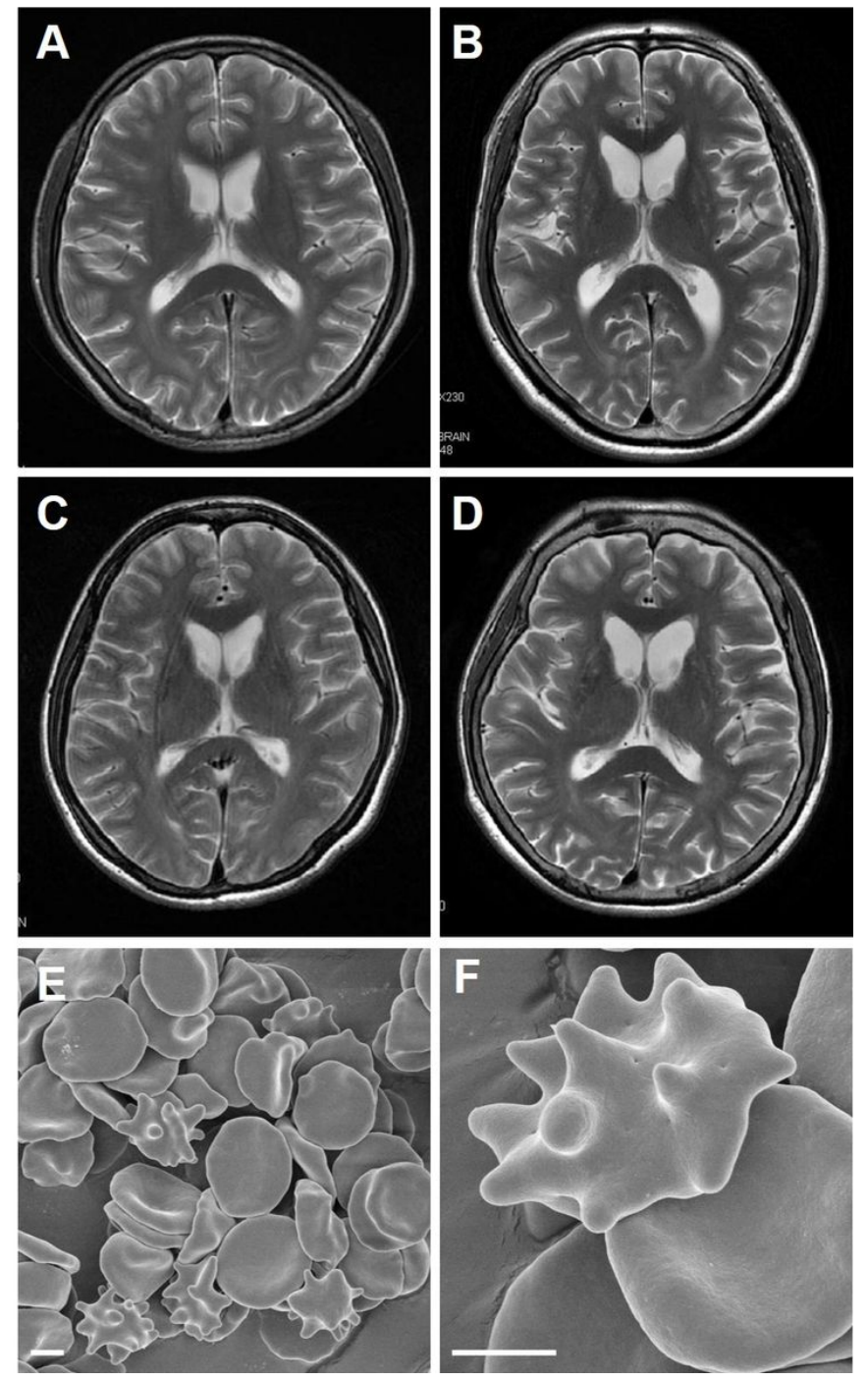

Figure 2

Clinical features of five genetically diagnosed patients. (A-D) Brain MRI of Case 1 (A), Case 3 (B), Case 4 (C) and Case 5 (D). Note the atrophy of caudate and the enlarged anterior horns of lateral ventricles. (E-F) Pictures of acanthocytes in peripheral blood of Case 5 by scanning electron microscopy. Scale bar: $2 \mu \mathrm{m}$.

\section{Supplementary Files}

This is a list of supplementary files associated with this preprint. Click to download.

- Tables1.docx 